\title{
Analisis Perbandingan antar Moda Distribusi Sapi : Studi Kasus Nusa Tenggara Timur - Jakarta
}

\author{
Tri Achmadi, Silvia Dewi Kumalasari, Hasan Iqbal Nur, Pratiwi Wuryaningrum \\ Institut Teknologi Sepuluh Nopember (ITS) Surabaya Jl. Arif Rahman Hakim, Sukolilo, Surabaya Indonesia \\ vivi.silvia@live.com
}

\begin{abstract}
Abstrak
Daging sapi merupakan komoditi utama daging di Indonesia, salah satu daerah dengan konsumsi daging sapi tertinggi yakni DKI Jakarta. Sehingga dibutuhkan pasokan sapi dari Salah satu daerah pemasok sapi terbesar di Indonesia yakni NTT sebagai sentra produksi untuk pemenuhan permintaan daging sapi DKI Jakarta. Namun kondisi pengiriman sapi dari NTT - Jakarta tidak sesuai dengan animal welfare, sehingga dioperasikan kapal ternak KM camara Nusantara 1 dengan kapasitas 500 sapi, dengan rute NTT - Jakarta dengan tujuan untuk menurunkan harga daging sapi di Jakarta. Dalam pengoperasiannya kapal tersebut pada pengiriman kedua dan ketiga kapal tidak bermuatan dikarenakan pemilik sapi lebih memilih menggunakan pengiriman cara lama. Sehingga perlu dilakukan analisis perbandingan distribusi sapi NTT - Jakarta pengiriman cara lama dengan moda kapal ternak. Tujuan dari penelitian ini untuk mengetahui moda terpilih pengiriman sapi dari NTT - Jakarta berdasarkan 3 aspek yakni unit biaya pengiriman, waktu pengiriman dari peternakan hingga rumah pemotongan hewan, dan, produksi daging sapi. Serta dari moda terpilih tersebut didapatkan pola operasi yang optimum untuk distribusi sapi NTT Jakarta. Metode yang digunakan dalam penelitian ini menggunakan metode komparasi dan optimasi dengan memperhatikan variabelvariabel yang berpengaruh. Dari penelitian ini didapatkan hasil perbandingan yang paling menguntungkan untuk distribusi sapi NTT Jakarta untuk pelabuhan asal Tenau Kupang yakni skenario 1 dengan hasil perbandingan total 9 miliar rupiah dan untuk skenario 2 dengan pelabuhan asal Waingapu, hasil perbandingan total 8,9 miliar rupiah, dengan moda terpilih kapal ternak, pola operasi port to port, rute Waingapu - Jakarta.
\end{abstract}

Kata Kunci-Distribusi sapi, Perbandingan antar moda

\section{PENDAhUluan}

Konsumsi daging sapi mencapai 19 persen dari jumlah konsumsi daging nasional [1]. Konsumsi daging sapi cenderung meningkat dari tahun ke tahun. Pada tahun 2006 mencapai 4,1 kg/ kapita/tahun meningkat menjadi 5,1 kg/kapita/tahun pada tahun 2007[2]. DKI Jakarta merupakan salah satu kota dengan kebutuhan akan daging sapi yang tinggi, dengan peningkatan kebutuhan sapi sekitar 2000 ekor per tahun. Untuk memenuhi kebutuhan akan daging sapi tersebut Jakarta harus mendapat pasokan dari berbagai daerah pemasok sapi, salah satunya yakni NusaTenggara Timur (NTT) sebagai sentra produksi sapi. Kondisi saat ini yakni pengiriman sapi dari NTT - Jakarta menggunakan dua alternatif pengiriman, yakni yang pertama menggunakan kapal general cargo yang dimodifikasi bagian deck diatas muatan digunakan untuk meletakkan sapi, sedangkan alternatif kedua yakni menggunakan kapal layar motor yang dilanjutkan dengan truck. Dengan keadaan tersebut menyebabkan ternak sapi hanya memiliki ruang terbatas, sehingga 5 konsep animal welfare tidak diterapkan [3]. Hal tersebut menyebabkan sapi mengalami penyusutan berat badan hingga $20-30$ persen atau bahkan mati selama perjalanan.

Dengan kondisi tersebut dioperasikan kapal ternak dengan fasilitas yang memadai untuk penunjang kebutuhan sapi. Kapal ternak tersebut dioperasikan dengan tujuan agar sapi yang dikirimkan dari NTT - Jakarta tidak mengalami stress yang akan berpengaruh pada produksi daging, meminimumkan biaya dan waktu pengiriman kapal sapi untuk menurunkan harga daging sapi di Jakarta, mengurangi risiko kematian sapi dan penyusutan bobot sapi, serta memenuhi standar internasional pengiriman sapi[4].

Kapal ternak tersebut telah beroperasi selama 3 kali pengiriman sapi dari NTT - Jakarta. Namun, pada pengiriman kedua kapal tersebut kosong. Pemilik sapi lebih memilih pengiriman sapi menggunakan moda transportasi yang lama. Berdasarkan kondisi tersebut diperlukan adanya perbandingan distribusi sapi kondisi yang lama dengan menggunakan kapal sapi dari NTT - Jakarta. Sehingga dalam tugas akhir ini dilakukan perhitungan perbandingan antar moda untuk distribusi sapi dari NTT Jakarta dari segi unit biaya pengiriman, produksi sapi, dan waktu pengiriman, serta penentuan pola operasi dari moda terpilih yang optimum. Manfaat dari penelitian ini yakni memberikan masukan dalam penentuan kebijakan pemilihan moda transportasi untuk distribusi sapi NTT - Jakarta, mengetahui efisiensi yang dihasilkan dengan adanya konsep distribusi sapi menggunakan kapal ternak dari NTT - Jakarta. 


\section{METODE PENELITIAN}

Metode pengumpulan data dalam penelitian adalah metode pengumpulan data secara langsung (primer), dan langsung (sekunder). Pengumpulan data ini dilakukan dengan mengambil data terkait dengan permasalahan dalam penelitian.

Tahap perhitungan dalam penelitan ini adalah perhitungan setiap komponen yang berhubungan dengan aspek perbandingan tiap moda yakni aspek biaya pengiriman, waktu, dan produksi daging sapi.

Tahap analisis dalam penelian ini meliputi analisis mengenai hasil dari perbandingan antar moda transportasi yang didapat akan dianalisa untuk mengetahui moda yang paling efektif untuk distribusi sapi dari NTT - Jakarta.

\section{ANALISIS DAN PEMBAHASAN}

\section{A. Skenario Perbandingan}

Pola distribusi sapi secara umum yakni sapi dikirimkan dari peternak sapi menuju pelabuhan asal menggunakan truk dengan kapasitas untuk satu truk yakni 8 ekor sapi untuk jeni sumba ongole dengan $450 \mathrm{~kg}$ per ekor. Kemudian dari pelabuhan asal ke pelabuhan tujuan dikirim menggunakan moda laut dengan kapasitas yang berbeda sesuai dengan jenis angkutan. Ketika sapi sampai di pelabuhan tujuan, sapi tersebut di distribusikan ke RPH yakni Rumah Pemotongan Hewan dengan menggunakan truk berkapasitas 8 ekor per truk. Sapi tersebut langsung di distribusikan ke RPH dikarenakan tidak adanya lahan di daerah DKI Jakarta dan sekitarnya untuk proses penggemukan sapi, selain itu sapi - sapi tersebut telah memenuhi standar berat sapi layak jika sapi tersebut langsung dipotong[1]. Pola distribusi sapi yang mungkin jika ditinjau dari segi kemungkinan berdasarkan pelabuhan asal tempat pemuatan sapi dan pelabuhan tujuan tempat bongkar sapi, dapat dilihat pada gambar berikut :

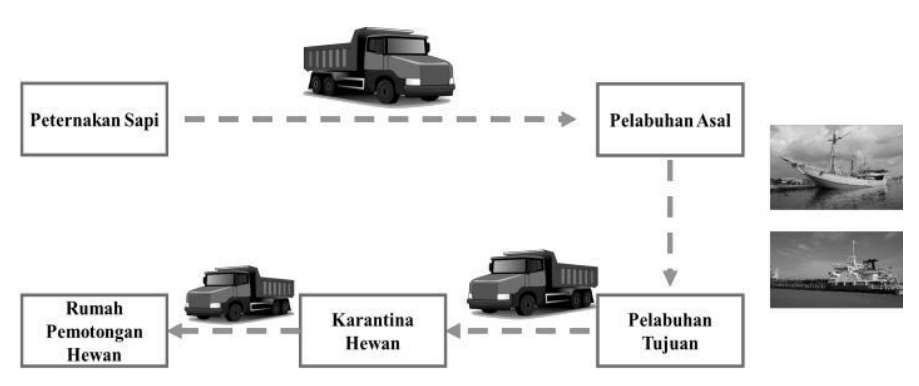

Gambar 1. Pola Distribusi Sapi Secara Umum

Dalam penelitian ini terbagi menjadi 2 skenario berdasarkan pelabuhan asal tempat muat ternak yakni skenario 1 pelabuhan asal Tenau Kupang, dan scenario 2 pelabuhan asal Waingapu.

B. Komponen Perbandingan

Dari masing - masing skenario didapatkan hasil analisis perbandingan yang terdiri dari 3 aspek yakni waktu, unit biaya pengiriman, dan perbandingan produksi daging, dengan perhitungan sebagai berikut :

1) Waktu Pengiriman

Komponen perhitungan total waktu pengiriman sebagai berikut:

1. Waktu dari peternak ke pelabuhan asal, meliputi :

a. Kecepatan truk

b. Kecepatan bongkar dan muat sapi ke truk

c. Jarak yang ditempuh

2. Waktu dari pelabuhan asal ke pelabuhan tujuan, meliputi:

a. Waktu pelayaran

b. Jarak yang ditempuh

c. Kecepatan kapal

d. Kecepatan bongkar muat sapi

3. Waktu dari pelabuhan tujuan ke rumah pemotongan hewan, meliputi :

a. Kecepatan truk

b. Kecepatan bongkar dan muat sapi ke truk

c. Jarak yang ditempuh

Dari komponen perhitungan total waktu pengiriman tersebut, terdapat beberapa komponen waktu pengiriman yang diabaikan dari segi administrasi, yakni proses pengajuan di dinas peternakan dan pertanian, dan proses karantina sapi.

Terdapat perbedaan komponen waktu pengiriman berdasarkan moda dengan ketentuan sebagai berikut :

1. Proses pengajuan dokumen di dinas peternakan dan pertanian untuk mendapatkan surat izin apakah bobot sapi memenuhi standar untuk di distribusikan, proses tersebut selama kurang lebih 3 hari, sedangkan khusus untuk kapal ternak dipermudah menjadi 1 hari[5]. 
2. Proses bongkar muat berdasarkan kecepatan alat bongkar muat. Kondisi bongkar dan muat untuk kapal ternak lebih lama jika dibandingkan kapal general cargo dan kapal layar motor dikarenakan lebih memprioritaskan kesejahteraan hewan.

3. Proses karantina sapi merupakan proses yang bertujuan untuk mengecek kondisi sapi yang bebas dari berbagai penyakit, proses tersebut selama 14 hari. Sedangkan untuk kapal ternak dipermudah menjadi 2 hari untuk mempercepat proses pengiriman sapi [1].

Sehingga didapatkan hasil perbandingan waktu pengiriman sebagai berikut:

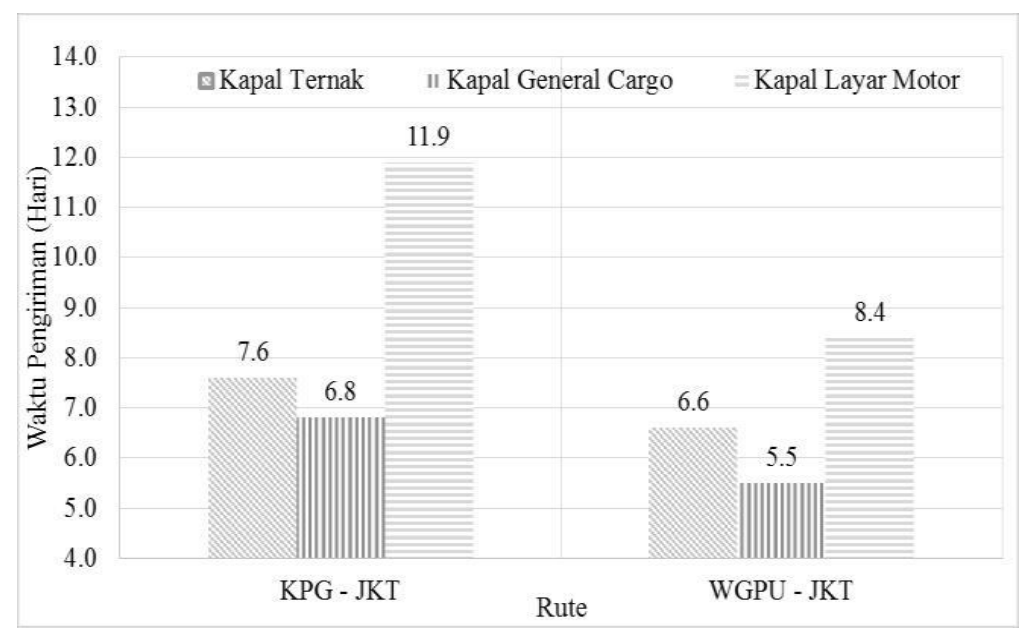

Gambar 2. Grafik Perbandingan Waktu Distribusi Sapi (Hari/Voyage)

Dari perbandingan waktu tersebut dapat diuangkan dengan menggunakan opportunity cost yakni biaya peluang yang hilang jika barang tersebut tertunda selama beberapa hari. Sehingga dapat disimpulkan bahwa ketika pengiriman barang semakin lama, maka opportunity cost yang hilang akan barang tersebut semakin mahal, begitupun sebaliknya. Kesimpulannya jika barang tersebut lebih cepat untuk sampai maka opportunity cost semakin murah. Dengan persamaan opportunity cost sebagai berikut :

Opportunity Cost [Rp./Ekor] = Jumlah barang $x$ Harga Barang $x$ Suku bunga pinjaman (per hari) $x$ Lama penundaan barang (hari)

Dari persamaan tersebut diketahui bahwa :

- Suku bunga dasar kredit per tahun $12 \%$ dijadikan dalam satuan hari sehingga menjadi $0.033 \%$ per hari

- Kebutuhan sapi Jakarta yakni 8568 ekor per hari

- Harga sapi di Jakarta per ekor Rp 14.600.000

Sehingga didapatkan perbandingan waktu yang diuangkan yakni :

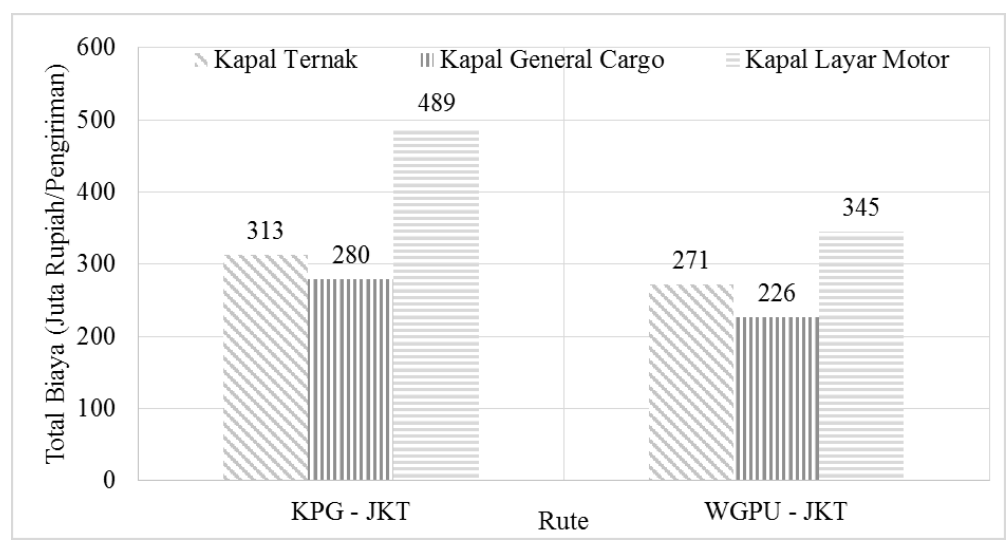

Gambar 3. Grafik Perbandingan Waktu dalam Rupiah (Opportunity Cost)

Dari gambar 3 perbandingan waktu dalam rupiah yakni paling murah kapal general cargo, dikarenakan semakin cepat barang itu sampai maka semakin sedikit opportunity cost, dan kebutuhan akan barang tersebut segera terpenuhi.

2) Unit Biaya Pengiriman

Dari perhitungan total waktu tersebut dapat dihitung biaya yang dibutuhkan untuk mendistribusikan sapi. Komponen perhitungan unit biaya pengiriman terdiri dari : 
1. Biaya dari peternak ke pelabuhan asal, meliputi :

- Biaya sewa truk

- Biaya bahan bakar

- Biaya supir truk

2. Biaya dari pelabuhan asal ke pelabuhan tujuan, meliputi:

- Voyage Cost

- Operational Cost

- Capital Cost

- Cargo Handling Cost

3. Biaya dari pelabuhan tujuan ke rumah pemotongan hewan, meliputi :

- Biaya sewa truk

- Biaya bahan bakar

- $\quad$ Biaya supir truk

Sehingga didapatkan perhitungan unit biaya pengiriman total dari peternakan hingga ke rumah pemotongan hewan sebagai berikut :

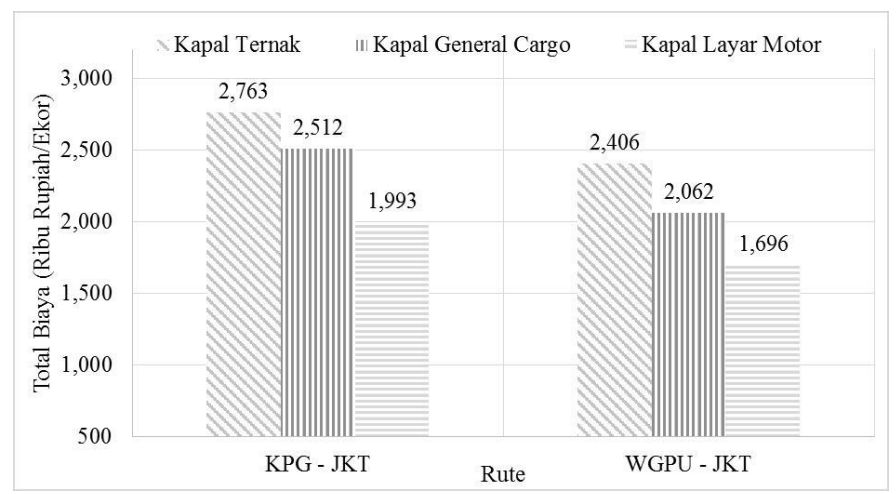

Gambar 4. Grafik Perbandingan Unit Biaya Pengiriman Distribusi + Opportunity Cost

Dari gambar 4 dapat diketahui bahwa distribusi sapi dari NTT - Jakarta paling murah untuk skenario 1 dengan unit biaya pengiriman $\mathrm{Rp}$ 1.993.229,00. per ekor menggunakan moda kapal layar motor, dan untuk skenario 2 dengan unit biaya pengiriman $\operatorname{Rp} \operatorname{Rp} 1.696 .269,00$.

\section{3) Produksi Daging Sapi}

Produksi daging sapi yang dihitung pada distribusi sapi dari NTT - Jakarta dilihat dari beberapa faktor penyusutan oleh pergantian moda, yakni meliputi :

1. Penyusutan distribusi sapi dari peternak ke pelabuhan asal, meliputi moda darat yakni truk tergantung lama waktu pengiriman dan perlakuan selama perjalanan [7].

2. Penyusutan dari pelabuhan asal ke pelabuhan tujuan, meliputi :

a. Susut berdasarkan moda transportasi

b. Kapal ternak sesuai animal welfare

c. Kapal general cargo tidak sesuai animal welfare

d. Kapal layar motor tidak sesuai animal welfare

3. Penyusutan dari pelabuhan tujuan ke rumah pemotongan hewan, meliputi moda darat yakni truk tergantung lama waktu pengiriman dan perlakuan selama perjalanan[6].

Faktor-faktor yang mempengaruhi penyusutan berat badan sapi menurut penelitian yang dilakukan di Division of Agricultural Sciences and Natural Resources, Oklahoma State University[7], yaitu:

1. Tipe pemberian pakan

Perubahan yang dialami oleh sapi yang diberikan kondisi pakan hijauan kering seperti di peternakan akan mengalami penyusutan sebanyak 3,5\% setalah dua jam perjalanan jika dibandingkan penyusutan sebanyak 5,3\% pada sapi yang diberikan pakan hijauan yang segar yang tidak seperti peternakan, penyusutan tersebut sekali selama 7 hari dalam perjalanan.

\section{Pergerakan sapi}

Ketika sapi bergerak dalam keadaan kondisi stress, mereka akan mengalami penyusustan berat badan. Yakni penyusutan setiap 30 menit satu kelompok sapi berjalan pada lintasan, diperkirakan akan kehilangan berat badan sekitar 0,5\%. Hal ini berhubungan dengan waktu yang ditempuh pada saat sapi bongkar muat karena sapi akan berjalan sesuai dengan panjang menuju paddock pada kapal.

3. Durasi perjalanan 
Waktu dan jarak adalah faktor yang penting. Penyusutan berat badan timbul ketika waktu transporasi awal dan meningkat secara berturut-turut. Sapi akan kehilangan berat badan sebanyak 1\% dari berat badannya untuk 3-4 jam pertama perjalanan, lalu akan kehilangan 3\% selama 8 jam perjalanan berikutnya jika tidak diberi makan selama perjalanan.

\section{Kondisi perjalanan}

Dengan saat pemuatan dan perjalanan pada jarak pendek saja bisa menyebabkan penyusutan bobot hingga 3\%. Kondisi bongkar muat yang tidak sesuai juga dapat menyebabkan gerakan yang berlebihan selama lebih dari 30 menit, yang akan menghasilkan luka dan penyusutan berat badan. Ketika sapi ditempatkan dengan sapi lainnya yang berasal dari peternakan yang sama, selama perjalanan sapi tersebut akan merasa seperti di peternakan, dan akan mengalami susut sebesar $0.25 \%$ tiap 8 jam perjalanan. Sedangkan ketika sapi ditempatkan dengan sapi yang berasal dari berbeda peternakan, sapi tersebut merasa asing dan mengalami stress sehingga susut sebesar $1 \%$ tiap 8 jam perjalanan.

Sehingga dari komponen tersebut dari perhitungan pada bab sebelumnya didapatkan perbandingan produksi daging sapi per ekor untuk distribusi sapi dari NTT - Jakarta yang didapatkan dari perhitungan faktor karkas dari bobot sapi yang dihasilkan dengan persamaan sebagai berikut :

\section{Faktor Karkas = Berat Sapi $(\mathrm{kg})$ x 55\% x 66\% = Produksi Daging Sapi $(\mathrm{kg})$ [2]}

Dari persamaan tersebut didapatkan produksi daging sapi sebagai berikut :

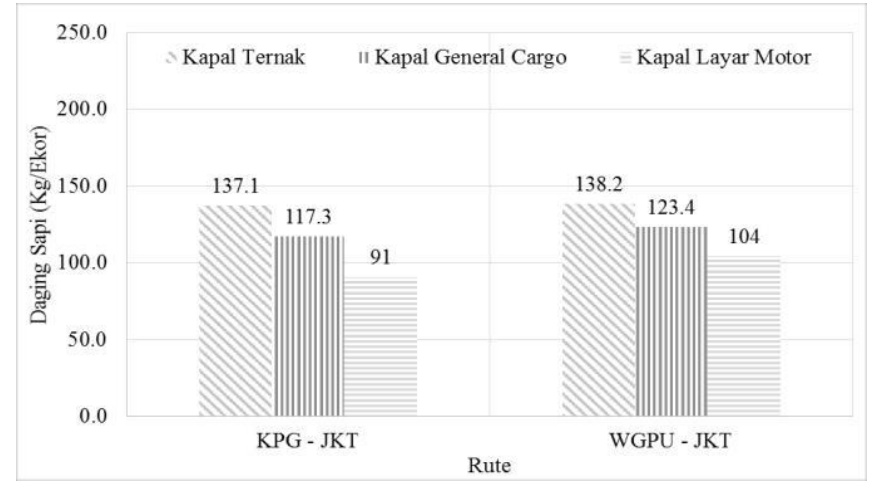

Gambar 5. Grafik Produksi Daging Sapi per Ekor Berdasarkan Skenario

Dari perbandingan perbandingan produksi daging sapi tersebut dapat diuangkan dengan menghitung harga daging sapi per $\mathrm{kg}$. Harga daging sapi per $\mathrm{kg}$ didapatkan dari :

$$
\text { Harga Daging Sapi per kg }=\frac{\text { Harga Sapi Normal per ekor }}{\text { Produksi Daging per ekor }}
$$

Sehingga dari persamaan didapatkan harga daging sapi per kg sebagai berikut :

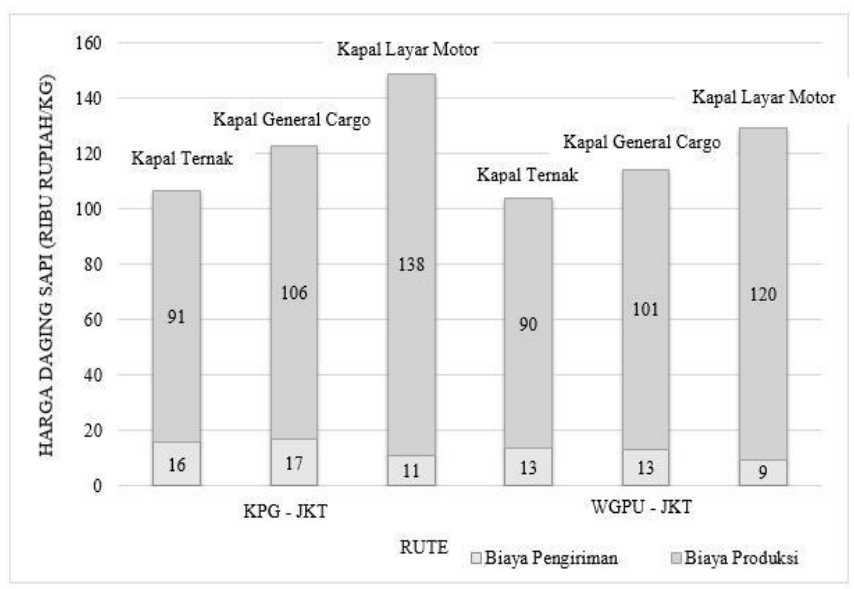

Gambar 6. Grafik Perbandingan Harga Daging Sapi

Dari gambar 6 perbandingan harga daging sapi per $\mathrm{kg}$ dalam rupiah yakni paling murah untuk skenario 1 dengan pelabuhan asal Tenau Kupang yakni moda kapal ternak sebesar Rp 106.000 per kg, sedangkan untuk skenario 2 dengan pelabuhan asal Waingpau menghasilkan hasil yang sama dengan skenario sebelumnya yakni kapal ternak dengan harga daging sebesar Rp 104.000 per kg. Hal tersebut dikarenakan semakin banyak daging yang diproduksi oleh satu sapi maka harga daging sapi per kg untuk satu sapi akan lebih murah.

\section{Hasil Perbandingan Moda Terpilih}

Dari ketiga komponen perhitungan diatas maka didapatkan moda terpilih dengan mengkonversi tiap komponen menjadi satuan yan sama yakni dikonversi dalam rupiah. Sehingga didapatkan hasil dari masing - masing konversi tiap komponen ke 
rupiah dan penjumlahan dari masing - masing komponen berdasarkan moda, sehingga didapatkan perbandingan sebagai berikut :

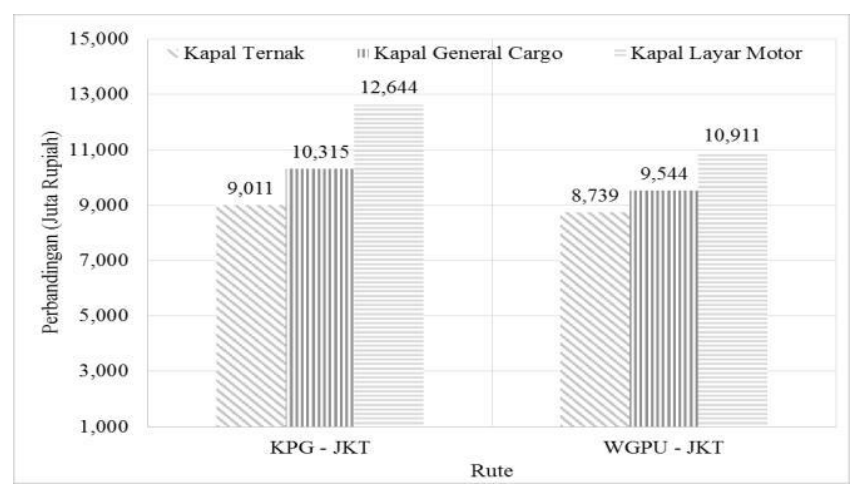

Gambar 7. Grafik Perbandingan Antar Moda dalam Rupiah

Perbandingan antar moda mengkonversi tiap komponen perbandingan ke rupiah dan dijumlah untuk masing- masing moda sehingga didapatkan moda terpilih. Moda terpilih yakni moda dengan minimum biaya, yakni dari gambar 5-12 diketahui bahwa dari pelabuhan asal Tenau Kupang dan Waingapu menghasilkan perbandingan antar moda yang sama yakni moda kapal ternak. Sehingga dapat disimpulkan moda terpilih yakni kapal ternak, moda dengan minimum biaya.Dari perbandingan perbandingan produksi daging sapi tersebut dapat diuangkan dengan menghitung harga daging sapi per kg. Harga daging sapi per kg didapatkan dari :

\section{KESIMPULAN}

Dari penelitian yang telah dilakukan maka diperoleh kesimpulan sebagai berikut :

1. Kondisi eksisting distribusi sapi dari NTT - Jakarta sebagai berikut :

- Perbandingan penggunaan moda sebelum adanya kapal ternak yakni 70\% kapal general cargo dan 30\% kapal layar motor.

- $\quad$ Rute eksisting moda kapal general cargo dan kapal layar motor yakni dari pelabuhan asal Tenau Kupang dan pelabuhan tujuan Tanjung Priok Jakarta, dengan pola operasi port to port. Sedangkan moda kapal ternak pola operasi multiport dengan rute eksisting Tenau Kupang - Waingapu - Jakarta.

- Frekuensi pelayaran eksisting yang dapat dilakukan untuk satu armada dalam setahun yakni kapal general cargo sebanyak 48 kali, kapal layar motor sebanyak 27 kali, kapal ternak sebanyak 24 kali.

- Unit biaya pengiriman moda eksisting dari pelabuhan asal sampai pada rumah pemotongan hewan untuk kapal general cargo yakni Rp 1.900.000, kapal layar motor yakni Rp 1.100.000, kapal ternak yakni Rp 600.000.

2. Hasil perbandingan antar moda distribusi sapi NTT - Jakarta yakni :

- Unit biaya pengiriman termurah yakni untuk pelabuhan asal Tenau Kupang skenario 1 dengan hasil perhitungan Rp 1.993.229 menggunakan moda kapal layar motor. Sedangkan untuk pelabuhan asal Waingapu yakni skenario 2 dengan hasil perhitungan Rp 1.696.018 dengan moda yang sama kapal layar motor.

- Dari segi waktu yang paling cepat dengan mengabaikan opsi waktu administrasi yakni untuk pelabuhan asal Tenau Kupang skenario 1 menggunakan kapal general cargo dengan total waktu pengiriman 6.8 hari, sedangkan untuk skenario 2 dengan pelabuhan asal Waingapu didapatkan total waktu pengiriman yang paling cepat dengan hasil menggunakan moda yang sama yakni selama 5.5 hari.

- Dari segi produksi daging, yang paling sedikit mengalami penyusutan untuk skenario 1 dengan pelabuhan asal Tenau Kupang yakni menggunakan moda kapal ternak dengan bobot sapi yang dihasilkan per ekor sebesar 378 $\mathrm{kg}$, dan produksi daging yang dihasilkan sebesar $137 \mathrm{~kg}$ per ekor sapi, sedangkan untuk skenario 2 dengan moda yang sama dihasilkan bobot sapi per ekor sebesar $381 \mathrm{~kg}$ dan produksi daging sebesar $138 \mathrm{~kg}$.

- Dari ketiga aspek perbandingan tersebut yakni segi unit biaya, waktu dan produksi daging sapi, yang dikonversikan ke nilai rupiah atau diuangkan moda yang terpilih yakni kapal ternak dengan hasil komparasi konversi ke rupiah total yakni sebesar Rp 9.010.160.084 untuk skenario 1, Rp Rp 8.900.685.398untuk skenario 2.

\section{DAFTAR PUSTAKA}

[1] Peternakan deansosekundip, "Sapi Peranakan Ongole,” 2016. [Online]. Available: http://peternakandeeansosekundip.blogspot.co.id/2012/10/sapi-po-peranakan-ongole.html.

[2] D. Peternakan, "Konsumsi Daging Sapi,” 2015.

[3] "In Animal Welfare Regulation,” 2016.

[4] tempo, "Tak dapat sapi kapal ternak jokowi pulang tangan kosong," 2016. [Online]. Available: 
https://bisnis.tempo.co/read/737372/tak-dapat-sapi-kapal-ternak-jokowi-pulang-tangan-kosong.

[5] Ezat, "Divisi pemasaran kapal dan barang," 2016.

[6] National Animal Welfare Advisory Comitte, "Transpor within New Zealand,” Anim. Welfare., 2011.

[7] S. Kent Barnes, "Managing Shrink and Weighing Conditions in Beef Cattle," Oklahoma State University, 2015. 